\title{
BOGDAN BIELA \\ Odnowa wspólnoty parafialnej w programowaniu duszpasterskim
}

Znaczacym problemem pastoralnym dla Kościola jest dzisiaj oslabienie wplywu środowiska chrześcijańskiego na ksztaltowanie wspólnoty żywej wiary i milości. Dawniej zadanie wychowania nowych pokoleń chrześcijan spelniała w glównej mierze rodzina wspierana przez środowisko spoleczne, przeniknięte $\mathrm{w}$ swych instytucjach i zwyczajach atmosferą chrześcijańską. W tych warunkach duszpasterstwo, ograniczające się do gloszenia słowa Bożego, szafarstwa sakramentów oraz stwarzania kultycznych ram służby Bożej, mogło uchodzić za wystarczające. Dzisiaj natomiast tego rodzaju minimalistyczne duszpasterstwo, nie wspierane pracą i oddzialywaniem środowiska wychowujacego, zawisło jakby w próżni i nie jest zdolne samo osiagnąc celu, jakim jest wychowanie chrześcijan żyjących wiarą i ksztaltujących swoje życie na fundamencie wiary.

Warunkiem wszelkiego postępu, odnowy, reformy jest krytyczne uświadomienie sobie i zanalizowanie aktualnych blędów i braków ${ }^{1}$. Wydaje się, że trzeźwe i realistyczne spojrzenie na sytuację duszpasterską Kościola w Polsce nie powinno nastrajać pesymistycznie. Najistotniejsze jednak zagrożenie tkwi w odnowie pozornej, czysto zewnętrznej, legalistycznej. Nie ma krajów uprzywilejowanych, sa tylko kraje o różnym stopniu zaawansowania i rozwoju tych samych $w$ gruncie rzeczy procesów. Doświadczenie ogólne jest jednoznaczne: tradycyjny model życia chrześcijańskiego i duszpasterstwa nie wytrzymuje próby wspólczesnych przemian. Jednak Sobór Watykański II z jego obrazem Kościola, ukazuje sposób przezwyciężania niedomagań i braków tradycyjnego modelu duszpasterstwa.

\footnotetext{
${ }^{1}$ F. B l a c h n i ck i: Katechetyka fundamentalna. Lublin 1979 s. 120.
} 
Mimo toczacej się wśród teologów dyskusji na temat parafii, stanowi ona podstawową osnowę organizacyjna duszpasterstwa. Ona bowiem jest ostatecznym umiejscowieniem Kościola (ChL 26). Dlatego też nie ma lepszej zasady duszpasterskiej, która ogarnialaby zarówno ludzi ochrzczonych, jak i będących jeszcze poza Kościolem. Aby jednak Kościól w Polsce stawal się żywą cząstką Kościola powszechnego, musi przejać się eklezjologią komunii, podejmując przede wszystkim trud odnowy duszpasterstwa parafialnego. Trydenckie principium parafii, które akcentuje wydzielenie terytorium z pewną grupą ludzi i powolanie odpowiedzialnego za nią pasterza, w efekcie prowadzi do tego, że wierni traktuja swoja parafię jako jedna $z$ instytucji ushugowych, zaspokajających ich potrzeby duchowo-religijne. Model tradycyjny przez swą centralizację staje się modelem statycznym, bez dynamiki. Nie można negować historycznego znaczenia tradycyjnego principium tworzenia parafii, opartego na zasadzie terytorialności, obecnie jednak już to nie wystarcza. Parafia musi być pojmowana jako miejsce urzeczywistniania się Kościola lokalnego we wspólnocie, ze wszystkimi elementami, które należą do konstytutywnych cech Kościola ${ }^{2}$. Dlatego też dziś nie wystarcza już dotychczasowe, tradycyjne duszpasterstwo, a więc duszpasterstwo bez programu, a niekiedy chaotyczne i mało przemyślane.

Urzędowe nauczanie Kościola ukazując znaczenie i rolę idei communio dla współczesnego Kościola, nie pokazuje konkretnego programu budowania parafii. Daje jednak mocny impuls, aby nowa ewangelizacja skoncentrowała się przede wszystkim na jej odnowie. Zobowiązuje to przede wszystkim strategów duszpasterstwa, którymi są w pierwszym rzędzie pasterze Kościola, do realizacji w ramach swoich wspólnot projektów odnowy parafii, bazujacych na eklezjologii komunii. Postulat ten wspólbrzmi ze slowami Jana Pawla II, który mówiąc w Adhortacji apostolskiej Novo millennio ineunte, że nie trzeba wyszukiwać „nowego programu" duszpasterskiego, wskazal jednocześnie, iż jest jednak konieczne, aby znalazl on wyraz we wskazaniach duszpasterskich dostosowanych do sytuacji każdej wspólnoty (...). Wlaśnie w Kościolach lokalnych można określić konkretne elementy programu - cele i metody pracy, zasady formacji i doskonalenia duszpasterzy i ich wspólpracowników, sposoby poszukiwania potrzebnych środków - dzięki którym orędzie Chrystusa może docierać do ludzi, ksztaltować wspólnoty (NMI 29). W świetle tych słów ciagle powinniśmy stawiać sobie fundamentalne pytanie: Czy nasze parafie i praca duszpasterska są szkołami komunii (por. NMI 43)? Inaczej mówiąc: Czy rzeczywiście to wszystko, co czynimy w duszpasterstwie zmierza do tego, by parafia stawala się wspólnotą ewangelizujących wspólnot? Pojawia się także pytanie: czy i na ile programy duszpasterskie w Polsce przyczyniają się do budowania parafii na miarę eklezjologii Vaticanum II?

${ }^{2}$ Por. J. R i g a 1: L'ecclésiologie de communion. Son evolution historique et ses fondements. Paris 2000 s. 69-72. 
Kluczem do odnowy wspólnoty parafialnej jest świadomość i akceptacja wspólnotowego modelu parafii przez tych, którzy za jej rozwój są szczególnie odpowiedzialni. Jeśli proboszcz nie będzie mial krytycznego spojrzenia na braki i niedomagania tradycyjnego modelu życia chrześcijańskiego i parafialnego, to nie podejmie inicjatywy w przeprowadzeniu nieodzownych reform zapoczątkowujacych systematyczną i dlugofalową pracę nad odnową parafii. Jedno z podstawowych zadań pasterzy zawiera się w szeroko pojętej promocji „Kościoła budującego wspólnotę” na rzecz „Kościola celebrującego”. Wiąże się z tym postulat realizacji duszpasterstwa ewangelizacyjno-katechumenackiego ${ }^{3}$. Zadanie to jest ściśle związane $z$ formacja laikatu, który wpierw trzeba odpowiednio przygotować do wspólodpowiedzialności za misję Kościola oraz do najrozmaitszych poslug we wspólnocie lokalnej. W związku z tym trzeba dostrzec i uznać istniejące na terenie parafii grupy, stowarzyszenia, wspólnoty i ruchy oraz podjąć z nimi wspólpracę.

Aby parafia stawala się ,szkolą komunii” (por. NMI 43) musi podjać wieloletni plan dzialania zbudowany na eklezjologii communii. Warunkiem nieodzownym jego realizacji jest świadomość posiadania przez duszpasterzy integralnej i organicznej wizji budowania wspólnoty lokalnej. Pasterz parafii ogarnia wtedy calość procesu rozwojowego, który ma prowadzić do urzeczywistnienia wspólnoty Kościola. Proces ten rozpoczyna się od ewangelizacji, która inicjuje procesy wyzwoleńcze $w$ ludziach i danym środowisku. Kolejnym etapem jest wdrażanie poprzez formację katechumenalną do życia w eklezjalnej wspólnocie. Glównym wnioskiem wyplywającym z faktu, że Kościól urzeczywistnia się w lokalnych wspólnotach jest postulat, by cale duszpasterstwo bylo tak przebudowane, aby slużyło formowaniu podstawowych wspólnot życia chrześcijańskiego w parafii. Sa one pośrednimi etapami w budowaniu parafialnej więzi wspólnotowej. W nich jest możliwe istnienie komunikacji międzyosobowej, shużącej w efekcie budowaniu parafii jako wspólnoty wspólnot ${ }^{4}$. Oprócz wspólnoty prezbiterium parafialnego, parafialnej rady duszpasterskiej oraz malych wspólnot religijnych, należy zwrócić szczególną uwagę na rodziny, jako podstawowe wspólnoty parafii.

Realizując budowanie modelu wspólnotowego, parafie duże pod względem liczebności wiernych powinny być podzielone na mniejsze jednostki organiza-

${ }^{3}$ Por. A. Ż a dło: Parafia w trzecim tysiqcleci. Kielce 1999 s. 50-53; F. B la c h n i c ki: Sympatycy czy chrześcijanie? Katechumenat na dzisiejsza godzin. Krościenko 2002 s. 100; D. Z i m o ń: Miejsce na mistagogię w roku liturgiczny. W: Mistagogia a duchowość. Red. A. Ż ą d ło. Katowice 2004 s. 64-68.

${ }^{4}$ F. B l a c h n i ck i: Etapy realizacji wspólnotowego modelu parafii. Wizja Ruchu ŚwiatloŻycie. „Koinonia”. R. 1979 nr 2 s. 12-20; T e n ż e: Formacja slużby liturgicznej jako jedna z form mlodzieżowego deuterokatechumenatu w parafii. „Collectanea Theologica”. A. 46: 1976 fasc. $4 \mathrm{~s}$. 51. 
cyjne. Istniejace w nich wspólnoty sąsiedzkie, moga stać się najbliższa każdemu katolikowi, najbardziej rodzinną, mała, podstawową wspólnotą kościelną. To w nich i poprzez nie, świeccy moga spelniać swoją podmiotowość w Kościele. Takie wspólnoty ewangelizują swoje środowisko, wychowując do świadomej wiary i wspólodpowiedzialności. Jawi się w zawiązku z tym pilna potrzeba, aby w każdej parafii istniał strategiczny plan urzeczywistniania modelu parafii wspólnotowej. Pomoca w realizacji wspólnotowego modelu parafii na plaszczyźnie programowania i planowania moga slużyć posoborowe ruchy odnowy Kościoła realizujące wypracowane przez siebie projekty odnowy parafii, a więc posiadajace konkretny sposób budowania parafii wspólnoty wspólnot. Do bardziej znanych zaliczyć można program „Nowy Obraz Parafii”, ,system ewangelizacyjnych komórek parafialnych”, projekt „parafia wspólnota wspólnot” oraz nasz rodzimy - „Nowa Wspólnota”.

W parafii wspólnotowej głębokiej refleksji wymaga sposób wypelniania poshugi proboszcza. Proboszcz we „wspólnocie wspólnot” ma być ośrodkiem, wokól którego koncentruje się życie wspólnot parafialnych, a nie wierzcholkiem piramidy. Jest on tym, który ogarnia całość. On musi wiedzieć do czego dzialalność duszpasterska zmierza, na jakim etapie znajduje się budowana wspólnota, jakie muszą być uruchomione procesy. Koordynowanie, kierowanie tym procesem według określonej wizji, to jest jego glówne zadanie. W urzeczywistnianiu parafii wspólnotowej duszpasterzy powinien wspomagać zespól, którym może być rada parafialna. Ważne zadanie stoi przed grupami podejmującymi różne posługi w parafii. Istnienie grupy koordynujacej prace, a także zespolu diakonii jest nieodzowne w budowaniu parafii jako wspólnoty wspólnot.

W kontekście odnowy wspólnoty parafialnej dogłębnego przemyślenia domaga się również koncepcja proponowanych co roku przez Komisję Duszpasterstwa Konferencji Episkopatu Polski tzw. programów duszpasterskich. Problem ten byl już aktualny kilkadziesiąt lat temu, gdy programy duszpasterskie na stałe wchodzily do pracy duszpasterskiej Kościola w Polsce. Już w latach siedemdziesiątych ubiegłego wieku nasz wybitny polski pastoralista, ks. Franciszek Blachnicki podczas jednej z konferencji do kaplanów na temat organizacji życia parafialnego, mówil: Nie pomagaja tutaj plany duszpasterskie, którymi próbuje się odgórnie ratować i wypetniać próznię, dlatego, że te plany też nie bazuja na wizji calościowej, teologicznej. Raczej chodzi o jakieś mniej lub więcej zgrabne dobranie pewnych hasel $i$ zrobienie z tego tematów. Jednak nie jest to oparte na analizie faktycznej sytuacji naszego katolicyzmu, bo tej nie ma w skali globalnej, i nie jest oparte na zasadach wspólczesnej teologii pastoralnej ani na soborowej wizji Kościola i jego urzeczywistniania się w świecie wspólczesnym. Na pewno

${ }^{5}$ Zob. B. B i e la: Parafia miejscem urzeczywistniania się komunii Kościola. Katowice 2006 S. $565-591$ 
tam sq zawsze rzeczy pożyteczne i dobre, i jakoś potrzebne. Natomiast realizacja tych hasel jest czysta fikcja bo jezeli się hasła czy programy duszpasterskie przekazuje na poczqtku danego roku na szczeblu centralnym, to zanim dojda do szczebla wykonawczego, zwykle rok mija i już jest nowy program. I tak co roku się »odfajkowuje "te plany. Oczywiście, dziala tu jeszcze caly system zasadniczy zwyczajnego duszpasterstwa parafialnego, zwiqzanego ze sprawowaniem sakramentów. Faktycznie tworzy on gros naszego duszpasterstwa $i$ gdyby nawet nie byto planów duszpasterskich, to by i tak to wszystko szlo, albo mimo tych planów to $i$ tak idzie. $W$ gruncie rzeczy jest to dziewięćdziesiat procent duszpasterstwa. Odgórnie patrzy się na wszystko przez plany, a oddolnie to widać, jak mato te plany w końcu znaczq $w$ parafii, kto się specjalnie przejmuje planami. Wiadomo, że jeśli jest najważniejsza katecheza, to nie jest to zależne od co roku zmienianych planów. Podobnie kwestia sakramentów: od chrztu aż do pogrzebu, sprawa coniedzielnej eucharystii, praktyki sakramentu pokuty. Wszystko to idzie niezależnie od planów odgórnych. Tu się też zarysowuje pewien kryzys z powodu braku jakiejśs dlugofalowej wizji i świadomości celu, do czego to wszystko ma w końcu zmierzać? . $^{2}$

Oprócz kwestii związanej z percepcja programu duszpasterskiego na poziomie parafii - i nie chodzi tylko tutaj o odpowiedni czas ich publikacji czy też o chęci poszczególnych duszpasterzy - trzeba podkreślić, iż jeśli nie przejmiemy się soborowym modelem budowania parafii jako wspólnoty wspólnot, żadne „tradycyjne” plany czy programy duszpasterskie nie spelnią swej roli. Nie sa bowiem w stanie wejść w świadomość a tym bardziej w życie parafii. Problem więc $\mathrm{w}$ istocie dotyczy modelu organizacji duszpasterstwa parafialnego, a także modelu budowania parafii. Dlatego też, gdy ciagle w naszym duszpasterstwie dominuje model duszpasterstwa kultycznego, rodzi się pytanie, czy programowanie duszpasterskie nie powinno zajać się przede wszystkim parafią a konkretnie pomoca w realizacji wspólnotowego modelu parafii. Chodzi tu - jak nam podpowiadal Jan Pawel II w Adhortacji apostolskiej Christifideles laici-o przystosowanie struktur parafialnych $z$ dużq elastycznościq, jakq $w$ tej dziedzinie dopuszcza Kodeks Prawa Kanonicznego, majqc na względzie udzial świeckich w odpowiedzialności duszpasterskiej oraz o tworzenie niewielkich podstawowych wspólnot kościelnych, zwanych także wspólnotami żywymi, w których wierni moga przekazywać sobie nawzajem Slowo Boże oraz stużyć innym i praktykować milość. Wspólnoty te sq prawdziwym wyrazem kościelnej komunii i ośrodkami ewangelizacji, działającymi w lączności ze swoimi pasterzami (nr 26).

Podsumowując możemy powiedzieć, że Sobór Watykański II i posoborowa eklezjologia pastoralna uczynila wiele, aby Kościól byl wyraźniej rozumiany i urzeczywistniany jako komunia (por. ChL 19). Jeżeli duszpasterskie działanie

${ }^{6}$ F. B l a c h n i c k i: Rekolekcje dla wspólnoty kaplanów Chrystusa Stugi. Lublin 1991 s. 7. 
Kościola chce być duszpasterstwem dojrzalym, odpowiadającym soborowym kryteriom i adekwatnym do dzisiejszych czasów, musi konsekwentnie na wszystkich swych szczeblach akcentować wspóluczestnictwo, wspóludzial i wspólodpowiedzialność. Tylko wtedy bowiem będzie mogło być nazwane duszpasterstwem organicznym, czyli takim, gdzie nie ma miejsca na dominację, na indywidualizm, na zastępcza dzialalność lub na pasywność. Wszyscy w nim staja się w pelni odbiorcami i slugami tego samego i jedynego misterium zbawienia. Apostolstwo świeckich i poshuga duszpasterzy do tego stopnia się wzajemnie uzupelniaja, że działalność jednych, bez zaangażowania drugich, nie jest w pelni skuteczna (por. KKK 900, DA 10). To radykalne stwierdzenie - wedlug Jana Pawła II - odczytywać należy w świetle eklezjologii komunii, wedlug której wszystkie poslugi i charyzmaty, różne i zarazem komplementarne, sq konieczne dla rozwoju Kościola, każdy na swój własny sposób (ChL 27). Kościól sformalizowany i zdominowany przez duchowieństwo staje się nieatrakcyjny dla ludzi z inicjatywa. Utrwala postawy bierne oraz prowadzi do slabej identyfikacji ze wspólnotą Kościoła. Utrzymywanie takiego stanu rzeczy jest szkodliwe i równoznaczne ze sprzyjaniem zewnętrznym nurtom dechrystianizacyjnym.

Drugi Polski Synod Plenarny stwierdzil, iż należy usilnie starać się o ksztaltowanie modelu parafii jako wspólnoty wspólnot ${ }^{7}$. Wezwanie synodu jest powtórzeniem i aktualizacją nauki Soboru Watykańskiego II, by doprowadzić do rozkwitu poczucie wspólnoty parafialnej (por. KL 42). Podstawowy problem polega jednak na tym, że nasze rozumienie chrześcijaństwa jest wciąż zbyt zindywidualizowane. Parafia nie powinna być przede wszystkim miejscem, w którym każdy „zalatwia” swoje sprawy z Bogiem, ale winna być przestrzenią budowania komunii z Bogiem i wzajemnych, twórczych relacji z innymi ludźmi. Ponadto, mówiąc o parafii trzeba pamiętać, że jej rolą nie jest tylko opieka duszpasterska i posługa sakramentalna wśród praktykujących katolików. Dzisiaj szczególnie niezbędnie konieczna jest poglębiona świadomość misyjna. Kościól w Europie i na wszystkich kontynentach musi sobie zdawać sprawę z tego, że jest wszędzie $i$ zawsze Kościolem misyjnym (»in statu missionis«). Misja należy do jego natury tak bardzo, ze nigdy i nigdzie, nawet w krajach o ugruntowanej tradycji chrześcijańskiej, Kościól nie może nie być misyjny".

Nowa ewangelizacja nie jest możliwa bez udziału wiernych świeckich, którzy są swoistym pomostem pomiędzy oddalonymi od Kościoła a parafią. Aby jednak świeccy mogli wykonywać to zadanie, sami muszą mieć oparcie w malych wspólnotach, gdzie systematycznie mogą poglębiać swoją wiarę i uczyć się konkretnych sposobów apostolskiego zaangażowania. W tej perspektywie dopie-

${ }^{7}$ Potrzeby i zadania nowej ewangelizacji na przelomie II i III Tysiaclecia Chrześcijaństwa. W: II Polski Synod Plenarny (1991-1999). Poznan 2001 s. 22.

${ }^{8}$ J a n P a el I I: Pamięć i tożsamość. Kraków 2005 s. 119. 
ro widać pełny sens idei parafii jako wspólnoty wspólnot. W obecnych warunkach może ostać się jedynie „Kościól żywy”, w którym proklamowane jest slowo Boże, w którym obecna jest modlitwa, Eucharystia, świadectwo życia chrześcijańskiego, posługiwanie otrzymanymi charyzmatami, apostolstwo, jednym slowem Kościól, który jest „szkolą komunii”. Dlatego też proces przemiany duszpasterstwa parafialnego domaga się głębokich przemyśleń przede wszystkim ze strony samych pasterzy Kościoła.

Jest faktem, że do dziś nie zostaly wypracowane w polskim duszpasterstwie dlugoplanowe zasady odnowy parafii. Pomocą mogą z pewnością slużyć istniejace projekty odnowy parafii. Warto także, aby polskie parafie przeprowadzily na swoim terenie „,synody parafialne”, które moga dokonać diagnozy sytuacji w parafii, wspólnie określić cele oraz środki, jakimi będą dążyć do jej odnowy. Proces odnowy parafii to mozolne wdrażanie w życie przewidzianych dzialań, jak również ich korygowanie w zależności od zmieniających się potrzeb. Nie należy tu oczekiwać szybkich i spektakularnych osiagnięć. Odnowa parafii to zadanie zamierzone na dhugie lata. Można jednak ufać, że z biegiem czasu parafia świadomie realizująca proces odnowy stanie się wspólnota, która będzie znakiem i narzędziem zbawienia także dla ludzi oddalonych od Kościoła.

Wysilek pastoralny Kościola w Polsce winien zatem być skierowany przede wszystkim na odnowę parafii. Jednak parafii nie zmienią nawet najlepsze ogólnopolskie programy duszpasterskie. Dlatego też, aby te programy osiagnęly swój cel, potrzeba najpierw programu czy też planu budowania ewangelizacyjnokatechumenlanego modelu parafii wspólnoty wspólnot. I w tym wlaśnie może duszpasterzom pomóc wieloletni, obejmujacy cele, sposoby i środki program duszpasterski. Oczywiście konkretny sposób jego realizacji byłby już w gestii diecezjalnych gremiów pastoralnych. 